\title{
ESTIMATION OF SOME HEAVY METALS IN COW'S MILK IN ZAGAZIG CITY
}

\author{
ABDL-KHALIK A.; AZZA G.M. AYOUB and MONA TALAAT RASLAN \\ Animal Health Research Institute (Zagazig Branch)
}

\section{ABSTRACT}

Received at: 31/3/2013

Accepted: 1/7/2013
This study estimated the residues of some heavy metals of toxicological concern in milk. One hundred and fifty samples from dairy farm, market raw milk and vendors milk were collected from Zagazig City. Collected samples were examined for presence of lead $(\mathrm{Pb})$, cadmium $(\mathrm{Cd})$, mercury $(\mathrm{Hg})$ copper $(\mathrm{Cu})$ and Zinc $(\mathrm{Zn})$ by using atomic absorption spectrometry. The mean concentrations were 0.716 , 2.001, 2.11 for $\mathrm{Pb}$; 0.871, 3.39, 4.11 for $\mathrm{Cd}$; 0.911, 5.79, 6.37 for $\mathrm{Hg}$; 2.81, 7.21, 7.72 for zinc and $2.111,4.44,4.45(\mathrm{ng} / \mathrm{L})$ for copper in farms, markets and vendors milk samples, respectively. The percentages of significant dairy farms, market milk and vendor samples exceeded the maximum permissible limits were 30,44 and $52 \%$ for lead, 26, 100 and $100 \%$ for cadmium, 12, 22 and $28 \%$ for mercury, 22, 26 and 32\% for zinc, 50, 90 and $96 \%$ for copper. The statistical analysis regarding the data obtained from farms, markets and vendors milk revealed a low moderate and high significant differences in lead, copper, cadmium, mercury and zinc respectively. The public health and suggest precaution to minimize the level of such heavy metals in milk were discussed.

Key words: Heavy metals, Cows milk, Public health

\section{INTRODUCTION}

Inorganic or aggregated forms of chemical substances (metalloids, heavy metals etc..) in feed and food represent a severe risk for their long term toxicological effects. Heavy metals are widely dispersed in the environment. The toxicity induced by excessive levels of some of these elements such as cadmium $(\mathrm{Cd})$, lead $(\mathrm{Pb})$, Zinc $(\mathrm{Zn})$ and mercury (Hg) are well known (Kabzinski, 1998).

The toxic metal content of milk and dairy products is due to several factors in particular environmental conditions, the manufacturing process and the possible contamination during several steps of the manufacturing processes (Caggiano et al., 2005).

Milk contain most of the nutrients necessary for healthy food and in some groups such as children elderly, it may constitute the main food or even the only one (Lawrance and Friedman 1995 and Tripathi et al., 1999).

Heavy metal residues are highly toxic but many of them (e.g. copper and zinc) are essential activators for certain enzymes, vitamin and hormones, only at low concentrations. They are able to accumulate in the living tissues and organs leading to toxicity in man and animals. It is important to distinguish between their hazard effect and nutritional requirements (Garcia et al., 1999; Saad et al., 2001 and Llobet et al., 2003).
Heavy metals of toxicological concern are lead $(\mathrm{Pb})$, cadmium $(\mathrm{Cd})$, mercury $(\mathrm{Hg})$, copper $(\mathrm{Cu})$ and Zinc (Kabzinski, 1998). They are widely distributed in air, agricultural lands, water, effluents from heavy industries, drainage, fertilizers, sludge applied in the fields and stainless steel used in diary equipment (USEPA, 1993; Miner et al., 1997 and Naresh et al., 1999).

Copper, lead and cadmium are often deposited in lakes and streams from the air and considered as main source of water pollution that may be utilized by dairy animals or used for washing dairy utensils (Vesiland et al., 1990; Walker, 1999 and Enb et al., 2009).

In recent years, much attention has been paid to the possible danger of metal poisoning in human. It has been reported that lead, cadmium, zinc, copper and mercury are concentrated mostly in the kidney and liver leading to kidney damage and liver cirrhosis (Coggiano et al., 2005). They constitute severe threat to human health due to their cumulative nature resulting in cancer, renal failure, human hypertension, neuropathy of both central and peripheral nervous system, gastroenteritis, diabetes mellitus, anemia and ostiomalacia (Klopov, 1998; Eife et al., 1999 and Hagag and Fayz, 2012).

Because of the high risk associated with the consumption of milk with such toxic pollutants, the aim of the present study was to: determine the 
concentration of $\mathrm{Cd}, \mathrm{Pb}, \mathrm{Cu}, \mathrm{Zn}$ and $\mathrm{Hg}$ in farm, marked raw milk samples and vendors milk to set alarm for the public about their hazard effects.

\section{MATERIALS and METHODS}

The samples were collected in 8 areas places from Zagazig City with different pollution impact (high volume of traffic, industrial plants, dumps, wasteincinerators, metropolitan areas, small-medium towns, intensive agricultural activities).

\section{Collection of samples:}

A total of one hundred and fifty samples were collected from of dairy farms cow's milk, market raw milk and vendors (fifty of each), from 8 areas in Sharkia Governorate with different pollution impact (high volume of traffic industrial plants, dumpo, waste incinators, metro polition areas, small medium towns, intensive agricultural activities). The collected samples were aseptically collected and transferred to the laboratory to be examined for heavy metal residues.

Market raw milk samples were subjected to peroxidase test to exclude all samples proved to be heat treated according to Mendil, (2006).

\section{Preparation of samples:}

All samples were prepared according to FDA, (1993). Each milk sample was lyophilized and transferred into decontaminated polyethylene containers. The samples were then dried in an oven at $102^{\circ} \mathrm{C}$ for $6 \mathrm{hrs}$ to remove the trace of moisture. Slow charring was carried out on hot plate followed by calcination at $400^{\circ} \mathrm{C}$ for $6 \mathrm{hrs}$ in muffle furnace until white ash production. The ash was dissolved in one $\mathrm{ml}$ of nitric acid and made up to $25 \mathrm{ml}$ with double distilled water.

\section{Extraction of heavy metal according to Lameiras et al. (1998):}

Milk samples were extracted by adding $4 \mathrm{ml}$ of the prepared sample into polyethylene bottle with $10 \mathrm{ml}$ suspension solution composed of $0.5 \mathrm{~g}$ ammonium dihydrogen phosphate, $20 \mathrm{ml}$ ethanol, $50 \mathrm{ml}$ concentrated hydrogen peroxide and one $\mathrm{ml}$ concentrated nitric acid to $100 \mathrm{ml}$ deionized water. The mixture was mixed and filtered through $0.45 \mu \mathrm{m}$ membrane filter.

\section{Determination of heavy metals:}

Twenty microlitre of the filtrate were injected into the furnace $\left(\mathrm{HCA}-400^{\circ} \mathrm{C} \pm 10\right.$ ) and run for $6 \mathrm{hrs}$ until correlated peaks areas were obtained. Calibration was performed with aqueous standards prepared with the same suspension solution. Heavy metals were estimated using electrothermal atomic absorption spectrophotometer (ETAAS). Detection limits were calculated corresponding to three times of the standards. Accuracy was checked with recovery assays by adding known amount of standards to five different randomly samples and processing the mixtures as described for experimental samples according to Kabzinski, (1998) and Lameiras et al. (1998).

\section{RESULTS}

Table 1: Levels of heavy metals (ng/L) in dairy farm milk (cow's milk)

\begin{tabular}{|c|c|c|c|}
\hline Type & Minimum & Maximum & Mean \\
\hline Lead $^{*}$ & 0.004 & 1.024 & $0.716 \pm 0.025$ \\
\hline Cadmium $^{* *}$ & 0.009 & 2.251 & $0.871 \pm 0.035$ \\
\hline Mercury $^{* * *}$ & 0.003 & 1.113 & $0.911 \pm 0.003$ \\
\hline Zinc $^{* * * *}$ & 0.008 & 3.987 & $2.810 \pm 0.011$ \\
\hline Copper $^{*}$ & 0.022 & 3.798 & $2.111 \pm 0.014$ \\
\hline
\end{tabular}

Table 2: Levels of heavy metals (ng/L) in market raw milk samples

\begin{tabular}{lccc}
\hline \multicolumn{1}{c}{ Type } & Minimum & Maximum & Mean \\
\hline Lead $^{*}$ & 0.018 & 3.150 & $2.001 \pm 0.01$ \\
\hline Cadmium $^{* * *}$ & 0.030 & 5.680 & $3.390 \pm 0.32$ \\
\hline Mercury $^{* * *}$ & 0.050 & 9.450 & $5.790 \pm 0.12$ \\
\hline Zinc $^{* * * *}$ & 1.744 & 11.05 & $7.210 \pm 0.24$ \\
\hline Copper $^{*}$ & 0.310 & 6.410 & $4.440 \pm 0.12$ \\
\hline *Significant $(\mathrm{P} \geq 0.05)$ & $* *$ Significant $(\mathrm{P} \geq 0.01)$ & \multicolumn{2}{c}{$* * *$ Significant $(\mathrm{P} \geq 0.001)$}
\end{tabular}


Assiut Vet. Med. J. Vol. 59 No. 138 July 2013

Table 3: Levels of heavy metals (ng/L) in vendor milk samples

\begin{tabular}{|c|c|c|c|}
\hline Type & Minimum & Maximum & Mean \\
\hline Lead $^{*}$ & 0.019 & 3.260 & $2.113 \pm 0.02$ \\
\hline Cadmium ** & 0.031 & 5.811 & $4.119 \pm 0.51$ \\
\hline Mercury $^{* * *}$ & 0.061 & 10.240 & $6.371 \pm 0.12$ \\
\hline$Z_{\text {Zinc }}^{* * * *}$ & 1.788 & 11.02 & $7.721 \pm 0.22$ \\
\hline Copper $^{*}$ & 0.219 & 6.884 & $4.450 \pm 0.12$ \\
\hline
\end{tabular}

Table 4: The number of milk samples exceeded the maximum permissible limits

\begin{tabular}{|c|c|c|c|c|c|c|c|}
\hline \multirow{2}{*}{ Heavy metals } & \multirow{2}{*}{$\begin{array}{l}\text { Limits } \\
(\mathrm{ng} / \mathrm{L})\end{array}$} & \multicolumn{2}{|c|}{ Farm milk } & \multicolumn{2}{|c|}{ Market raw milk } & \multicolumn{2}{|c|}{ Vender milk } \\
\hline & & No. & $\%$ & No. & $\%$ & No. & $\%$ \\
\hline Lead & 0.05 & 15 & 30 & 22 & 44 & 26 & 52 \\
\hline Cadmium & 0.02 & 13 & 26 & 50 & 100 & 50 & 100 \\
\hline Mercury & 4.0 & 6 & 12 & 11 & 22 & 14 & 28 \\
\hline Zinc & 3.0 & 11 & 22 & 13 & 26 & 16 & 32 \\
\hline Copper & 0.3 & 25 & 50 & 45 & 90 & 48 & 96 \\
\hline
\end{tabular}

\section{DISCUSSION}

The percentages of the examined farm, market raw milk and vendors milk samples that exceeded the maximum permissible limits were in Table (4) 30, 44 and 52 for lead, 26, 100 and 100 for cadmium; 12, 22 and 28 for mercury; 22, 26 and 32 for zinc; 50, 90 and 96 copper. Nearly similar findings were reported by Saad et al. (2001).

The percentages of heavy above MRL in dairy farm milk may be attributed to agriculture practices, plants and fertilizers that remain in the feed consumed by dairy animals. This may lead to bioaccumulation of these metals in animal's tissues resulting in production of milk with high metal residues (Gengelbach and Spears, 1998 and Kodrik et al., 2011).

The most probable explanation for the high level of heavy metals in raw market milk may occur during milk transportation specially in polluted air, bad storage, contact with equipment employed as mechanical milkers, cadmium plated containers and tanker lorries. The transferred metals from equipment may exceed those originally present in the dairy farm milk (Coni et al., 1999 and Hagag and Fayz, 2012).

From the obtained results, it was clear from Tables (1, 2 and 3$)$ that the mean value of lead, cadmium, mercury, zinc and copper concentration in dairy farm milk, raw market milk and vendor milk were $0.716 \pm$
$0.025,2.001 \pm 0.01,2.113 \pm 0.02,0.871 \pm 0.035$, $3.390 \pm 0.32,4.11 \pm 0.51,0.911 \pm 0.003,5.790 \pm$ $0.12,6.371 \pm 0.12,2.81 \pm 0.011,7.210 \pm 0.24,7.721$ \pm 0.22 and $2.111 \pm 0.014,4.44 \pm 1.2,4.450 \pm 0.12$ $\mathrm{ng} / \mathrm{L}$, respectively.

Difference in cadmium $(\mathrm{P}>0.01)$ and high significant difference in mercury and zinc $(\mathrm{P}>0.01)$ were observed, respectively (Tables 1 and 2). The significant difference in $\mathrm{Cd}, \mathrm{Zn}$ and $\mathrm{Hg}$ nearly similar to the findings reported by Kirova (1995). Lower quantities were recorded by Carl, (1991) and Enas and Sharkawy, (1999).

On the other side, these high levels were reported by Fathi et al. (1997) and Naresh et al. (1999). This variation was probably attributed to the use of different analytical procedures.

The obtained results declared that the concentration of heavy metals in market raw milk samples considerably higher than those detected in dairy farm milk. This may be due to the different sources of samples which depend on the surrounding circumstances (Saad et al., 2001 and Kodrik et al., 2011).

According to the maximum permissible limits (MPL) of human daily intake recorded, continuous consumption of milk with such pollutants may lead to chronic toxicity including nervous system damage, mental retardation, kidney dysfunction, nausea, sever colic, diarrhea, persistent restlessness and long lasting 
rashes (Walker, 1999). Consumption of such milk particularly from polluted environment may pose human health hazards (Annon, 1996 and Zatterstrom, 1999).

\section{CONCLUSION}

To safe guard human health, a number of factors are to be into consideration for controlling heavy metal residues in milk starting from crop production by application good manufacturing practice, personal training and minimizing use of sludge for land fertilization, periodical monitoring of heavy metals in different types of milk.

\section{REFERENCES}

Annon, S. (1996): Clinical evaluation of livestock health hazards due to environmental pollution with particular references to fluorosis in domestic animal. R. and D Report ICAr. New Delhi, p. 58-76

Caggiano, R.; Sabia, S.; D'Emilio, M.; Macchiato, M.; Anastasio, A.; Ragosta, M. and Paino, S. (2005): Metal levels in fodder, milk, dairy products and tissue sampled in farms of Southered Italy. Environmental Research, 99 (1): 48-57.

Carl, M. (1991): Heavy metals and other trace elements monograph on residues and contaminants in milk and milk products. Chapter 6. International Dairy Federation, Belgium, p. 434-566.

Coni, E.; Bocca, B. and Caroli, S. (1999): Minor and trace element content of two typical Italian dairy products. J. Dairy Research 66 (2): 589-598.

Eife, R.; Weiss, M.; Barros, V.; Sigmund, B.; Goriup, U.; Komb, D.; Wolf, W.; Kittel, J.; Schramel, P. and Reister, K. (1999): Chronic poisoning by copper in tap water. Copper intoxication with predominately gastrointestinal symptoms. Eur. J. Med. Res. 4 (6): 219-233.

Enas, E.P. and Sharkawy, A.A. (1999): Estimation of some heavy metals in bovine milk in Assiut Governorate, Assiut Vet. Med. J. 41 (1): 153-169.

Enb, A.; Abou Donia, M.A.; Sbd-Robu, N.S.; Abo Arab, A.K. and El-Semaity, (2009): Chemical compotation during processing of milk product. Global Veterinaria, 3: 268-275.

Fathi, S.H.; Saad, M. and Elsawi, N.M. (1997): Trace metal level in some selected food. J. Egypt. Vet. Med. 57 (1): 165-178.

Food and Drug Administration "FDA" (1993): Pesticides and heavy metals analytical mannual. $2^{\text {nd }}$ Ed. Vol. 1, Washington, D.C. p. 123-151.
Garcia, E.; Lorenzo, M.; Cabrera, C.; Lopez, M. and Sanchez, J. (1999): Trace element determination in different milk slurries. J. Dairy Res. 66 (4): 569-578.

Gengelbach, G.P. and Spears, J.W. (1998): Effects of dietary copper and molybdinum on copper status and humoral immune response of calves. J. Dairy Sci. 81 (12): 3286-3292.

Hagag, M.F. and Fayz, S.A.E. (2012): Contamination of cow's milk by heavy metal in Egypt. Bull Environ. Contam. Toxicol., 88 (4): 611-613.

Kabzinski, A.K. (1998): Application of covalent affinity chromatography with thiol-disulfide interchanges for determination of environmental exposition to heavy metals based on the quantitative determination of $\mathrm{Zn}$ thionein from physiological human fluids by indirect method on analysis of metal content. Biomed. Chromatogr., 12 (5): 281-290.

Kirova, M. (1995): Content of lead in milk from an area of industrial pollution. Khranitelia Promishlenost., 44 (3): 21-22.

Klopov, P.V. (1998): Levels of heavy metals in women residing in the Russian Arctic. Int. J. Circumpolar Health, 57 (1): 582-585.

Kodrik, L.; Wagner, L.; Imre, K. and Husveth, F. (2011): The effect of highway traffico on heavy metals content of cow milk and cheese. Hungarian Journal of Industrial Chemistry Veszprem. 29 (1): 15-19.

Lameiras, J.; Scares, M.; Bastes, I. and Ferreira, M. (1998): Quantification of total cadmium in UHT milk by ETAAS. J. Analyst 123 (10): 2091-2095.

Lawrance, $R$. and Friedman, L. (1995): Contaminants in milk. In: Hand Book of Milk Composition (Jensen, G. Robert ed.) Academic Press $1^{\text {st }}$ ed. P. 857-990.

Llobet, J.M.; Falco, G.; Casas, C.; Teixido, A. and Domingo, J.L. (2003): Concentrations of arsenic, cadmium, mercury and lead in common food and estimated daily intake by children, adolescents, adult and seniors of Catalonia, Spain. J. Agric. Food Chem., 51: 838-842.

Mendil, M. (2006): Mineral trace metal level in some cheese collected from turkey. Chemistry, 96: 532-537.

Miner, G.; Guttierrez, R. and King, D. (1997): Soil factors affecting plant concentration of cadmium, copper and zinc on sludge amended soils. J. Environ. Qual. 26 (3): 989-994.

Naresh, R.; Dwivedi, K.; Swarup, D. and Dey, $S$. (1999): Lead and cadmium concentrations in milk and blood of Indian cows with mastitis. Vet. Hum. Toxicol., 41 (6): 392-393.

Saad, A.; El-Kosi, O. and Abdel-Hakiem, E. (2001): Surveillance of some heavy metals in raw milk. $1^{\text {st }}$ Cong. of Food Hygiene \& Human 
Health February. Dept. Food Hygiene, Fac. Vet. Med., Assiut University, p. 258-270.

Tripathi, M.; Raghunath, R.; Sastry, N. and Krishanamonnrthy, T. (1999): Daily intake of heavy metals by infants through milk and milk products. Sci. Tot. Environ., 9 (2): 229-235.

USEPA, "Environmental Protection Agency" (1993):

Clean water. Act. Section 503 Vol. 58 No. 32

USEPA. Washington, D.C., p. 343-351.
Vesiland, P.; Pierce, J. and Weiner, R. (1990): Water pollution. In: Environmental pollution and control. $3^{\text {rd }}$ Ed. London, Press, p. 15-36.

Walker, N.I. (1999): Copper toxicosis in an Australian child. Euro. J. Med. Res., 58 (6): 249-251.

Zetterstrom, R. (1999): Child health and environmental pollution in the Aral Sea region in Kazakhstan. Acta Paediatr. Suppl. 88 (4): 49-54.

\section{قياس بعض المعادن الثقيلة في لبن البقر في مدينة الزقازيق \\ أحمد عبد الخالق ، عزة جودة مصبلحي ، مني طلعت رسلان}

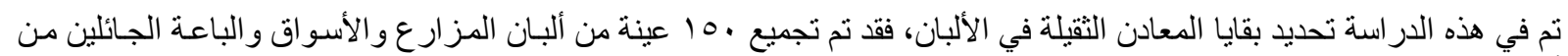

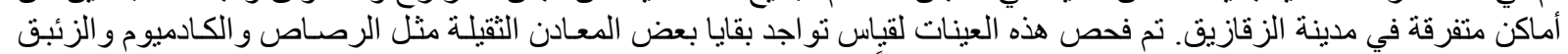

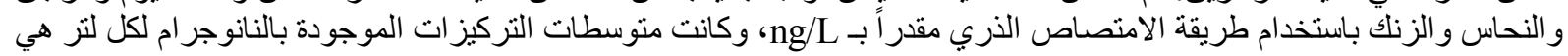

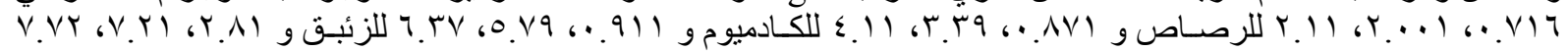

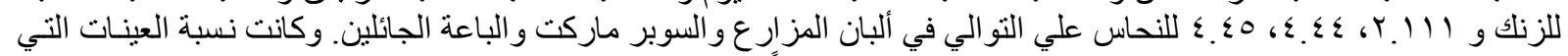

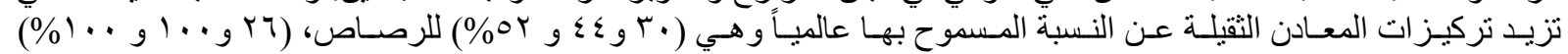

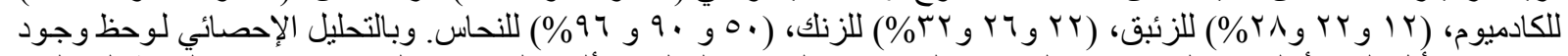

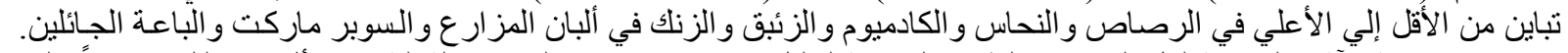

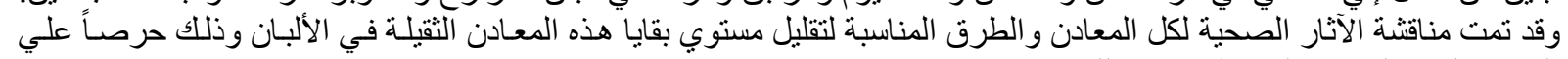

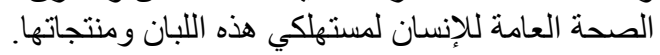

